\title{
PNNL-17953
}

Prepared for the U.S. Department of Energy under Contract DE-AC05-76RL01830

\section{Trends in U.S. Venture Capital Investments Related to Energy: 1980-2007}

JJ Dooley

October 2008

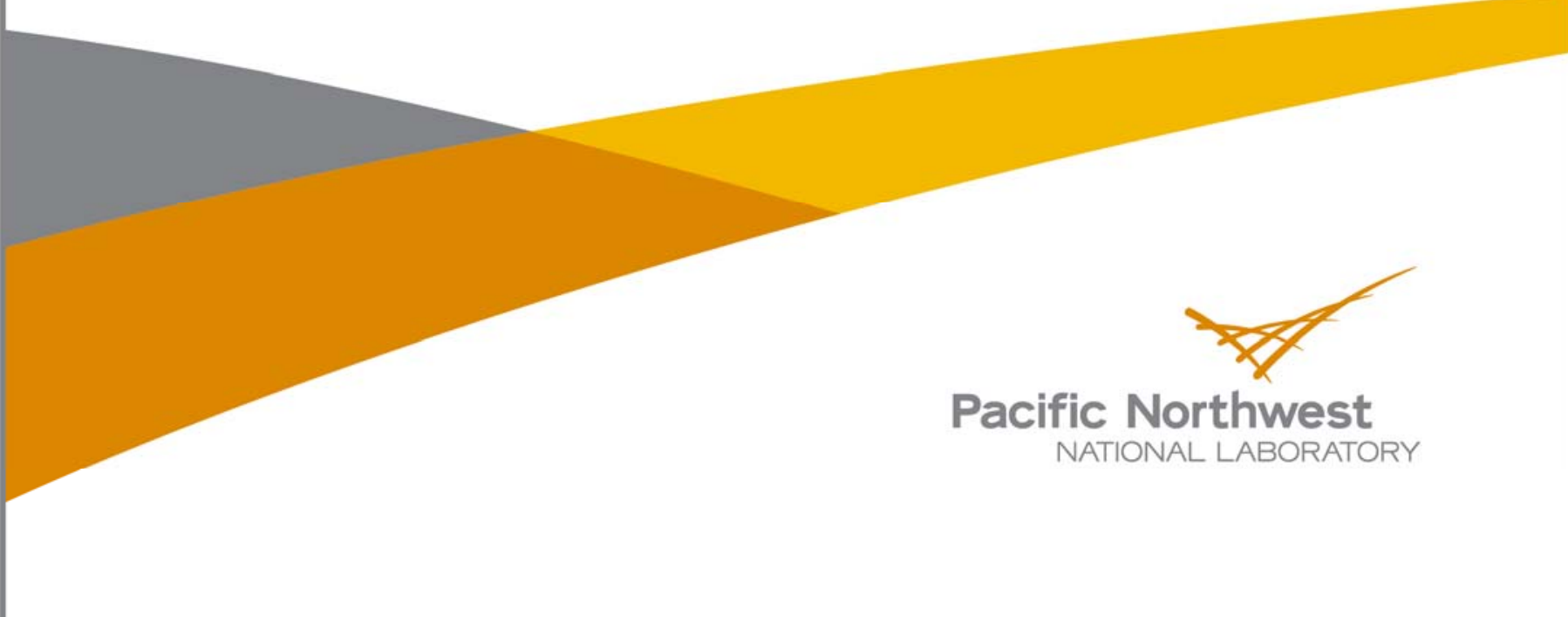




\title{
DISCLAIMER
}

This report was prepared as an account of work sponsored by an agency of the United States Government. Neither the United States Government nor any agency thereof, nor Battelle Memorial Institute, nor any of their employees, makes any warranty, express or implied, or assumes any legal liability or responsibility for the accuracy, completeness, or usefulness of any information, apparatus, product, or process disclosed, or represents that its use would not infringe privately owned rights. Reference herein to any specific commercial product, process, or service by trade name, trademark, manufacturer, or otherwise does not necessarily constitute or imply its endorsement, recommendation, or favoring by the United States Government or any agency thereof, or Battelle Memorial Institute. The views and opinions of authors expressed herein do not necessarily state or reflect those of the United States Government or any agency thereof.

\author{
PACIFIC NORTHWEST NATIONAL LABORATORY \\ operated by \\ BATTELLE \\ for the \\ UNITED STATES DEPARTMENT OF ENERGY \\ under Contract DE-AC05-76RL01830
}




\begin{abstract}
This report documents trends in U.S. venture capital investments over the period 1980-2008. Particular attention is given to U.S. venture capital investments for "internet-specific", biotechnology, and energy / industrial sectors over the period 1980-2007. During the early 1980s, U.S. venture capital investments in the energy / industrial area accounted for more than $20 \%$ of all venture capital investments. However subsequent periods of low energy prices and the emergence of fast growing new industries like computers (both hardware and software), biotechnology and the Internet quickly reduced the priority accorded to energy / industrial investments as by 2000 these investments accounted for only 1\% of the $\$ 119$ billion dollars invested that year by the U.S. venture capital community. The significant increase in the real price of oil that began in 2003-2004 correlates with renewed interest and increased investment by the venture capital community in energy / industrial investment opportunities. Venture capital investments in 2007 for the energy / industrial sector accounted for $\$ 3$ billion or slightly more than $10 \%$ of all venture capital invested that year.
\end{abstract}

KEY WORDS: venture capital; energy; energy technology; cleantech; United States. 


\section{Venture Capital does not Exclusively Imply High Technology}

It is important to note that while "venture capital" investments are often seen to be exclusively about the development of advanced technologies, this is not necessarily true. The National Venture Capital Association (NVCA) states clearly on their website that "Venture capital focuses on investing in private, young, fast growing companies” (NVCA, 2007). It is therefore more appropriate to read the data presented in this report as first and foremost a measure of what sectors and companies in the US economy venture capital funds believe have the best prospects for rapid growth and less so as a robust input measure of future technological development.

\section{U.S. Venture Capital Investments: 1980-2007}

Figure 1 shows total U.S. venture capital ${ }^{1}$ investments over the period $1980-2007 .^{2}$ While the general trend has been one of increasing venture capital investments with growth in this class of investments from $\$ 1.46$ billion in 1980 to $\$ 27.7$ billion dollars in 2007, it is also clear growth in venture capital investments has not been steadily increasing over this period. ${ }^{3}$

The large spike in venture capital activity in the late 1990s to the early 2000s is the most striking feature of Figure 1. In 2000, U.S. venture capital investments reached a record level of \$119 billion. Almost half (47\%) of the funding in this peak year was for "internet specific" 4 investments. Figure 2 shows how rapidly these "internet specific" U.S. venture capital investments rose and how quickly they declined in the run up to and subsequent aftermath of the bursting of the "dot.com bubble."

\footnotetext{
1 "U.S. venture capital investments are "defined here as investments made by U.S. controlled venture capital funds in U.S. based companies. The data here are believed to cover all stages of venture capital financing, e.g., Seed Stage, Later Stage, and Expansion Stage (NVCA 2008).

2 The principal data set used in this analysis represents the author's attempt to create a coherent and consistent temporal data set U.S. venture capital investments from 1980 to the present. Data describing these investments before 1980 are not publically available. The key data sources used to build this data set are: Data on venture capital investments for the period 1980-1989 are from NSB 2002; Data on venture capital investments for the period 1990-2004 are taken from NSB 2008; Data on venture capital investments for the period 2005-2007 are taken from PricewaterhouseCoopers/National Venture Capital Association, 2008.

${ }^{3}$ All financial data reported here are in inflation-adjusted, real 2005 U.S. dollars unless otherwise noted. The conversion of current, nominal, as-spent dollars (which is how most of these data are reported in the original source materials) to inflation-adjusted 2005 U.S. dollars was computed by using Gross Domestic Product Price Deflators taken from CEA, 2006.

${ }^{4}$ The National Venture Capital Association defines Internet-specific as "a discrete classification assigned to a company whose business model is fundamentally dependent on the Internet, regardless of the company's primary industry category (NVCA 2008).”
} 


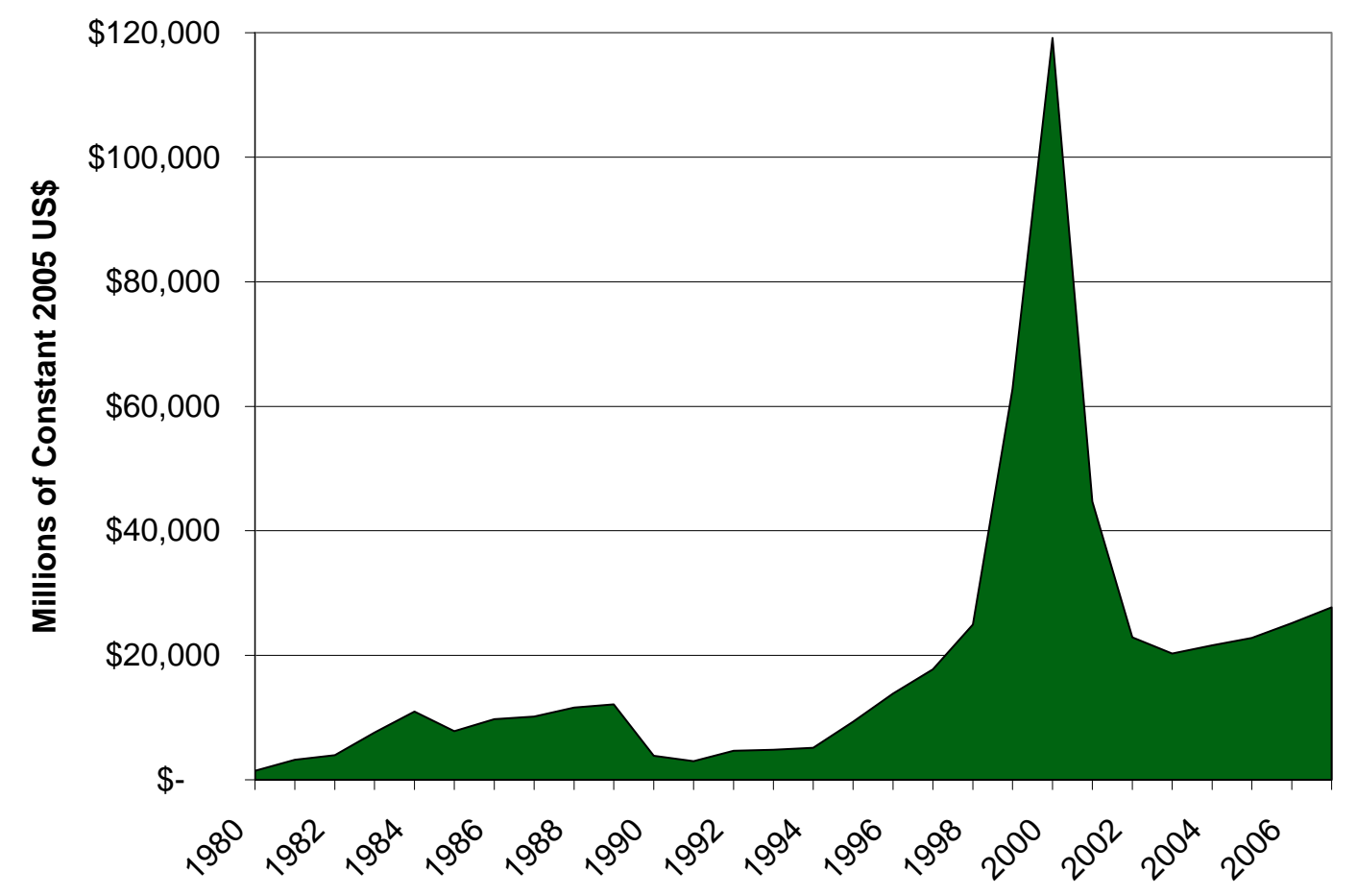

Figure 1: Total U.S. Venture Capital Investments in All Fields: 1980-2007 (millions of constant 2005 U.S. dollars)

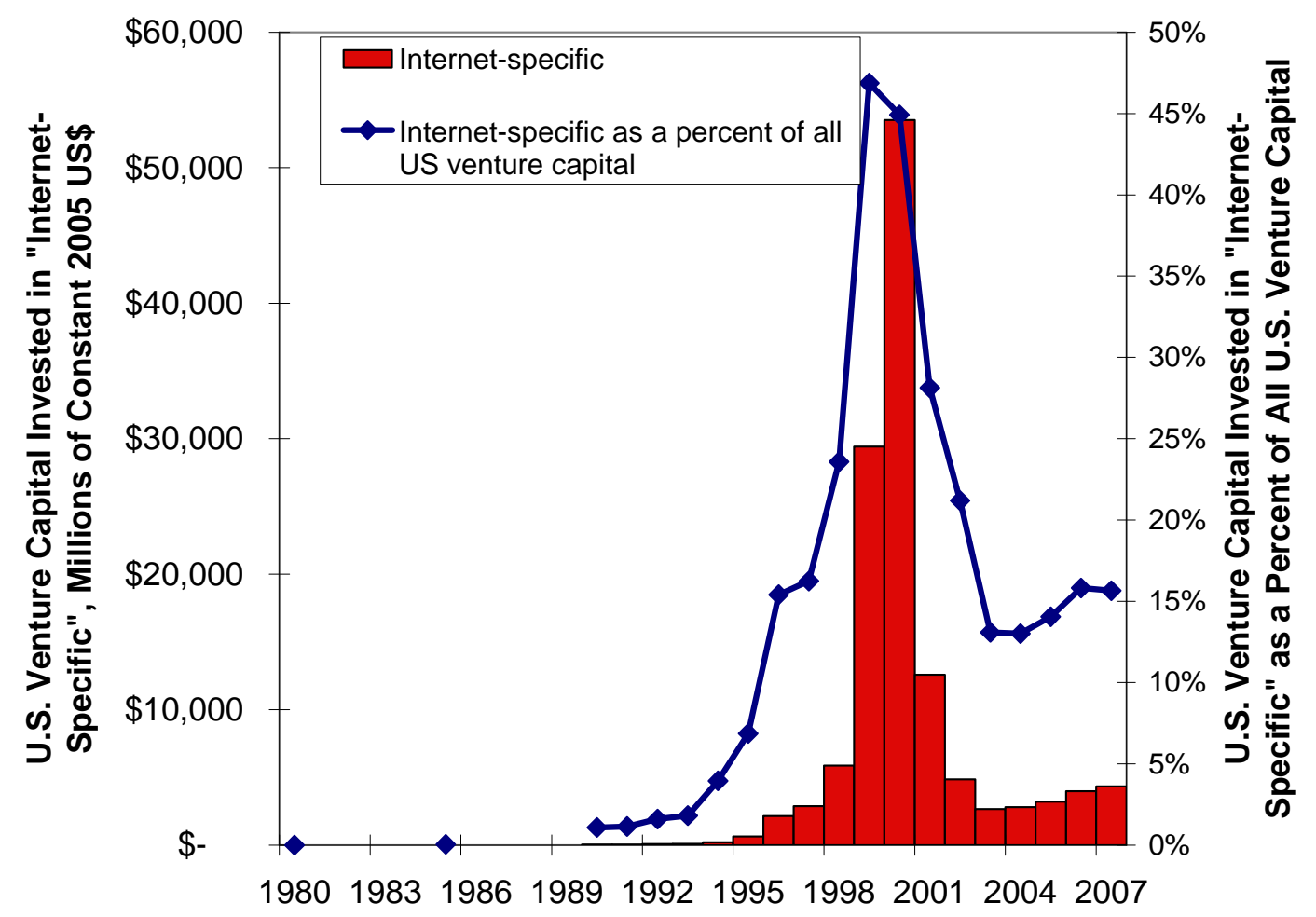

Figure 2: U.S. Venture Capital Investments in "Internet-specific" Firms: 1980-2007 (millions of constant 2005 U.S. dollars) 
Figure 3 shows venture capital investments in another key focus area for the U.S. venture capital community, the biotechnology industry. ${ }^{5}$ Biotechnology venture capital investments showed a similar spike during the dot.com bubble but investments in this area quickly rebounded and have been growing in absolute as well as relative terms since.

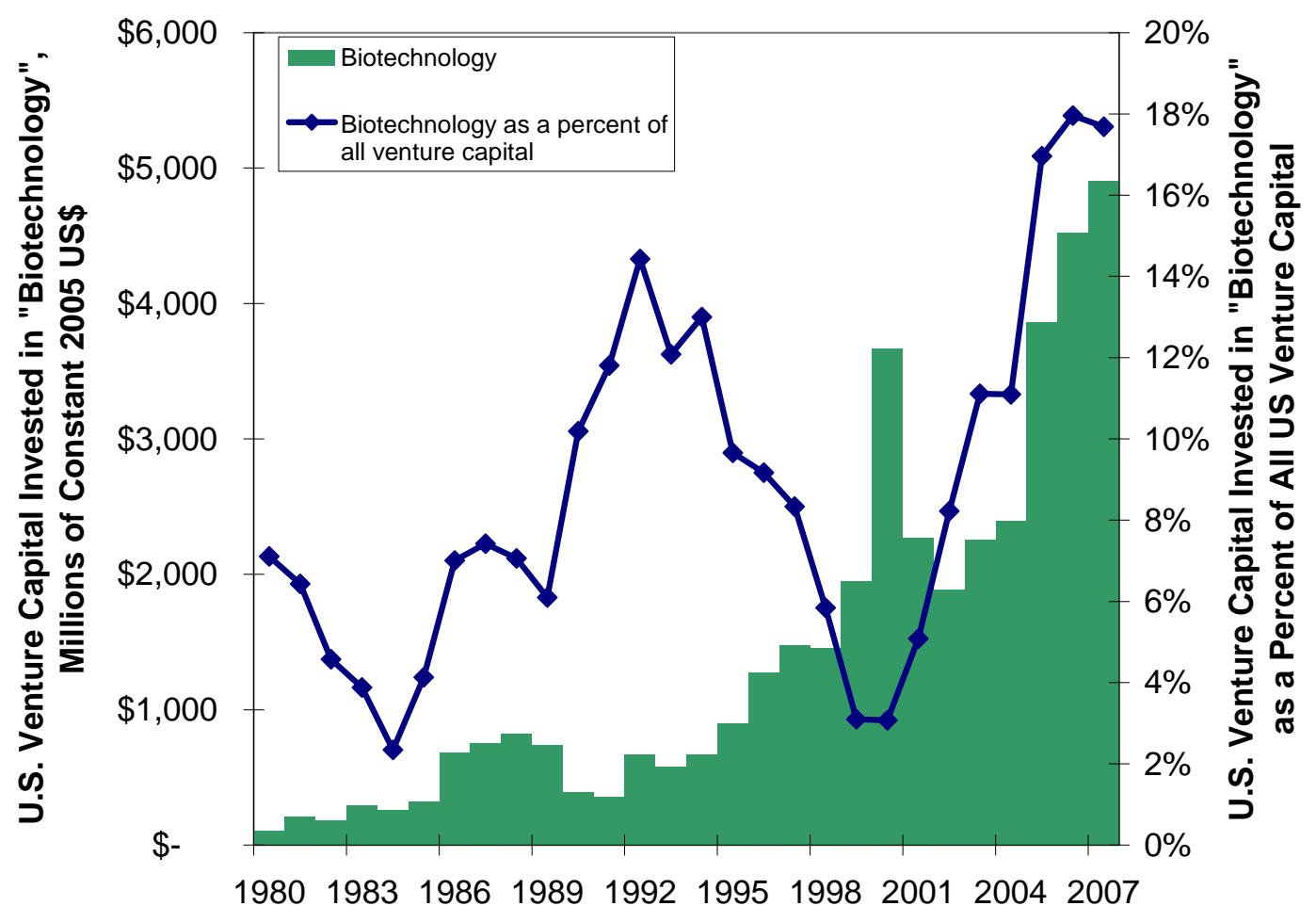

Figure 3: U.S. Venture Capital Investments in Biotechnology: 1980-2007 (millions of constant 2005 U.S. dollars)

Over the time period 1980-2007, a handful of industries typically garnered the majority (anywhere between 60-90\%) of the U.S. venture capital investments in a given year. These key industrial sectors are communications equipment, computer hardware, computer software, biotechnology, medical devices, and "internet-specific.” In many years since 1980, some of these sectors individually accounted for $20 \%$ or more of all venture capital spending. However, the priority accorded to these sectors shifted - often quickly - as the marketplace moved on to what was seen as the next high growth opportunity.

\footnotetext{
${ }^{5}$ Venture capital investments in "biotechnology” encompasses "Developers of technology promoting drug development, disease treatment, and a deeper understanding of living organisms. Includes human, animal, and industrial biotechnology products and services. Also included are biosensors, biotechnology equipment, and pharmaceuticals” (PricewaterhouseCoopers, 2008).
} 


\section{U.S. Energy Venture Capital Investments}

Figure 4 reports U.S. venture capital investments in the energy / industrial sector ${ }^{6}$ over the period 1980-2007. During the early 1980s, U.S. venture capital investments in the energy / industrial area accounted for more than $20 \%$ of all venture capital investments. This was during a period of high energy prices brought about by two major global oil crises as well as repeated high level statements from the U.S. government on the need to reduce U.S. dependence on imported energy and significant commitments of government and private sector funding for the development of new energy technologies.

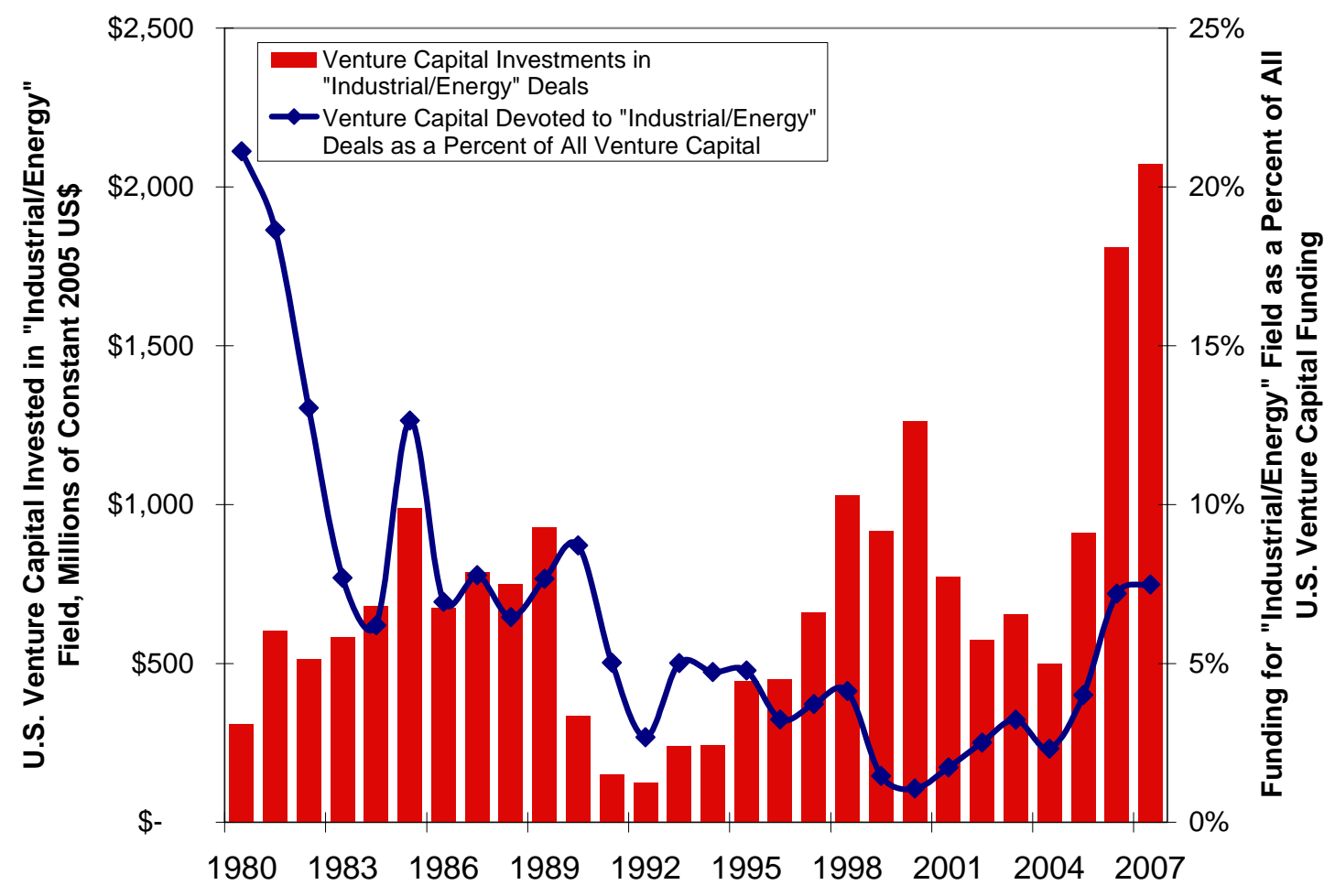

Figure 4: U.S. Venture Capital Investments in Energy / Industrial Sectors: 1980-2007 (millions of constant 2005 U.S. dollars)

However subsequent periods of low energy prices (see Figure 5), coupled with the Regan Administration's efforts to deregulate many aspects of the energy industry, as well as significant reductions in federal support for energy $\mathrm{R} \& \mathrm{D}$ and in particular the termination of a number of marquee "energy independence" technology development programs of the late 1970s, along with the emergence of fast growing new industries like computers (both hardware and software), biotechnology and the Internet led to the steady erosion of the priority accorded to energy / industrial investments by the U.S. venture capital community. By the early 1990s, energy / industrial investments were attracting less than 3\% of all U.S. venture capital and by 2000 these investments accounted for only $1 \%$ of the $\$ 119$ billion dollars invested that year by the U.S. venture capital community.

\footnotetext{
${ }^{6}$ U.S. venture capital investments in the "energy / industrial" sector are targeted at "Producers and suppliers of energy, chemicals, and materials, industrial automation companies and oil and gas exploration companies. Also included are environmental, agricultural, transportation, manufacturing, construction and utility-related products and services (PricewaterhouseCoopers, 2008a).
} 


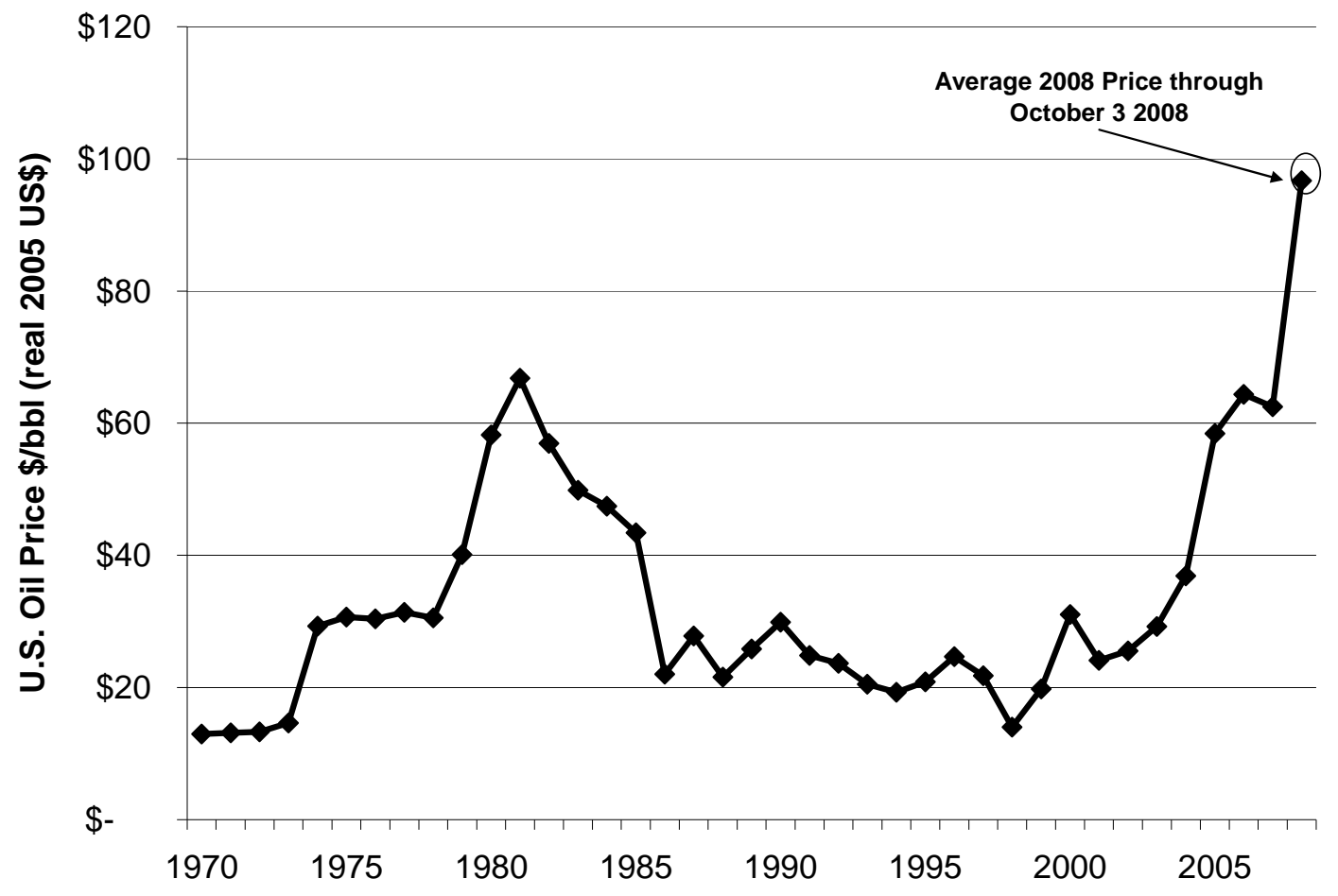

Figure 5: Average U.S. Oil Prices: 1970-2008 (millions of constant 2005 U.S. dollars)

The significant increase in the real price of oil that began in 2003-2004 correlates with renewed interest and increased investment by the venture capital community in energy / industrial investment opportunities. Venture capital investments in 2007 for the energy / industrial sector accounted for $\$ 3$ billion or slightly more than 10\% of all venture capital invested that year.

It is also instructive to look beyond these broad macro economy trends to try and understand what the U.S. venture capital community is now investing in with regard to energy. Figure 6 provides a snapshot of U.S. venture capital investments in the energy / industrial category for the fourth quarter of 2007 disaggregated by funding for each of "deals" / investments made that quarter. 


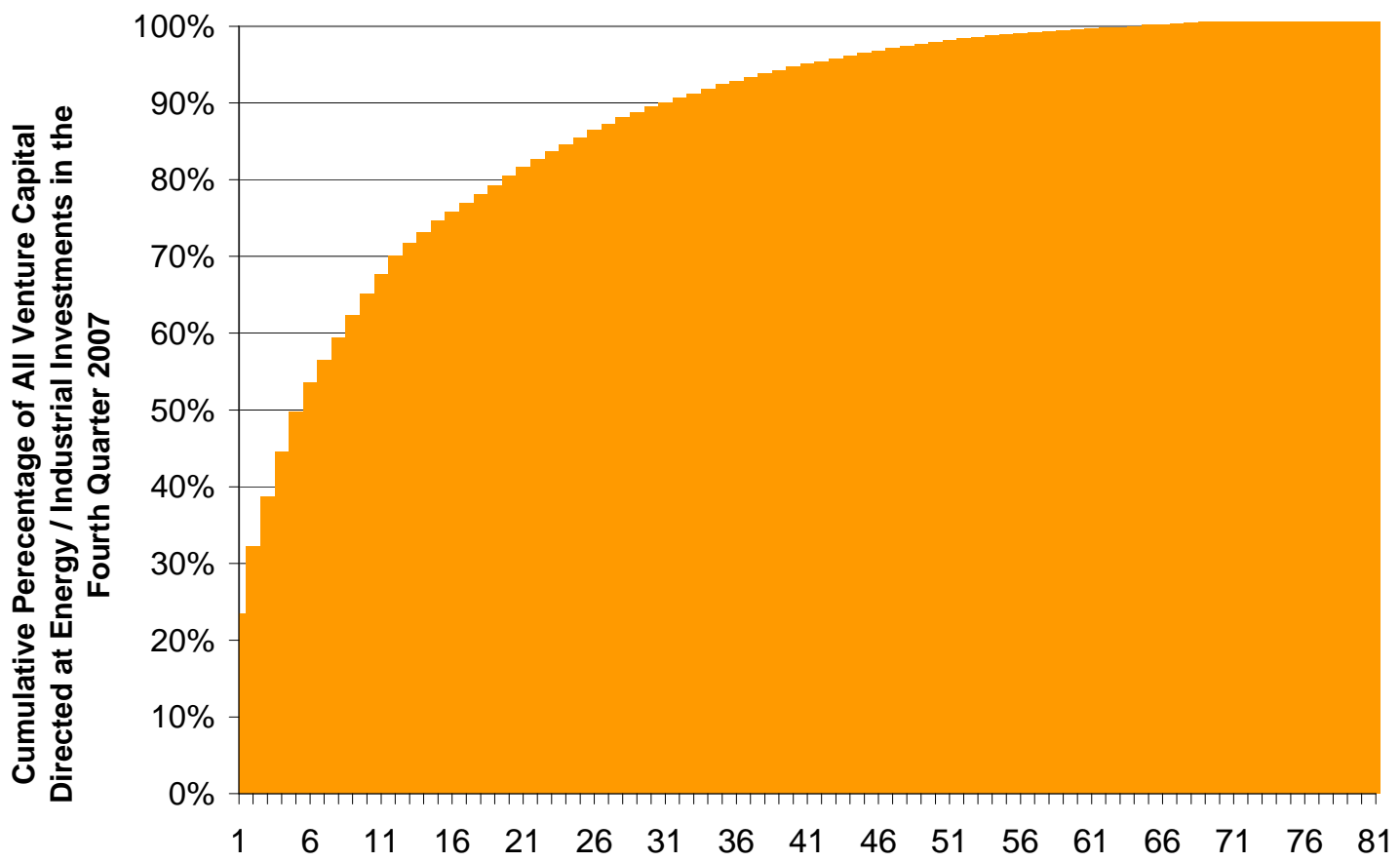

Number of Energy I Industrial Venture Capital Deals in the Fourth Quarter 2007

\section{Figure 6. Fourth Quarter 2007 U.S. Venture Capital Disbursements for the Energy / Industrial Sector}

During this three month period, \$854 million was invested in 81 deals yielding an average investment of \$10.5 million (PricewaterhouseCoopers, 2007). However it is clear from Figure 5 that the distribution of funding across these 81 deals was very uneven. The five largest deals captured half of all investments made that quarter. At the other end of the spectrum, are 26 companies that received $\$ 1$ million or less. Less than $20 \%$ of the energy / industrial deals during this quarter exceeded the "average” investment of \$10.5 million.

The five largest investments made in the fourth quarter of 2007 were $^{7}$ :

- \$200 million for Project Better Place: a start up designed to electrify large segments of the transportation sector by "having consumers subscribe to transportation services, much like they do today with mobile phones";

- $\$ 75$ million for iGPS: a company that enables more efficient transportation of goods by using reusable plastic pallets that contain Radio Frequency Identification (RFID) technologies to track shipments more accurately;

- $\quad \$ 55$ million for Everpower Renewables: a developer of utility scale wind power projects;

- \$50 million for Serious Materials LLC: a company that is developing a process to manufacture drywall that "produces no carbon dioxide" emissions;

- \$45 million for the Renewable Chemicals Corporation: a company that intends to use sugar cane-derived ethanol as a chemical feedstock.

\footnotetext{
${ }^{7}$ Quantitative data on the amounts invested in these five deals are from PricewaterhouseCoopers, 2007. The short descriptions of each company's activities are from the following sources: Project Better Place, 2008; iGPS. 2008; Erlich, 2007; EverPower Renewables, 2008, Reuters, 2008.
} 


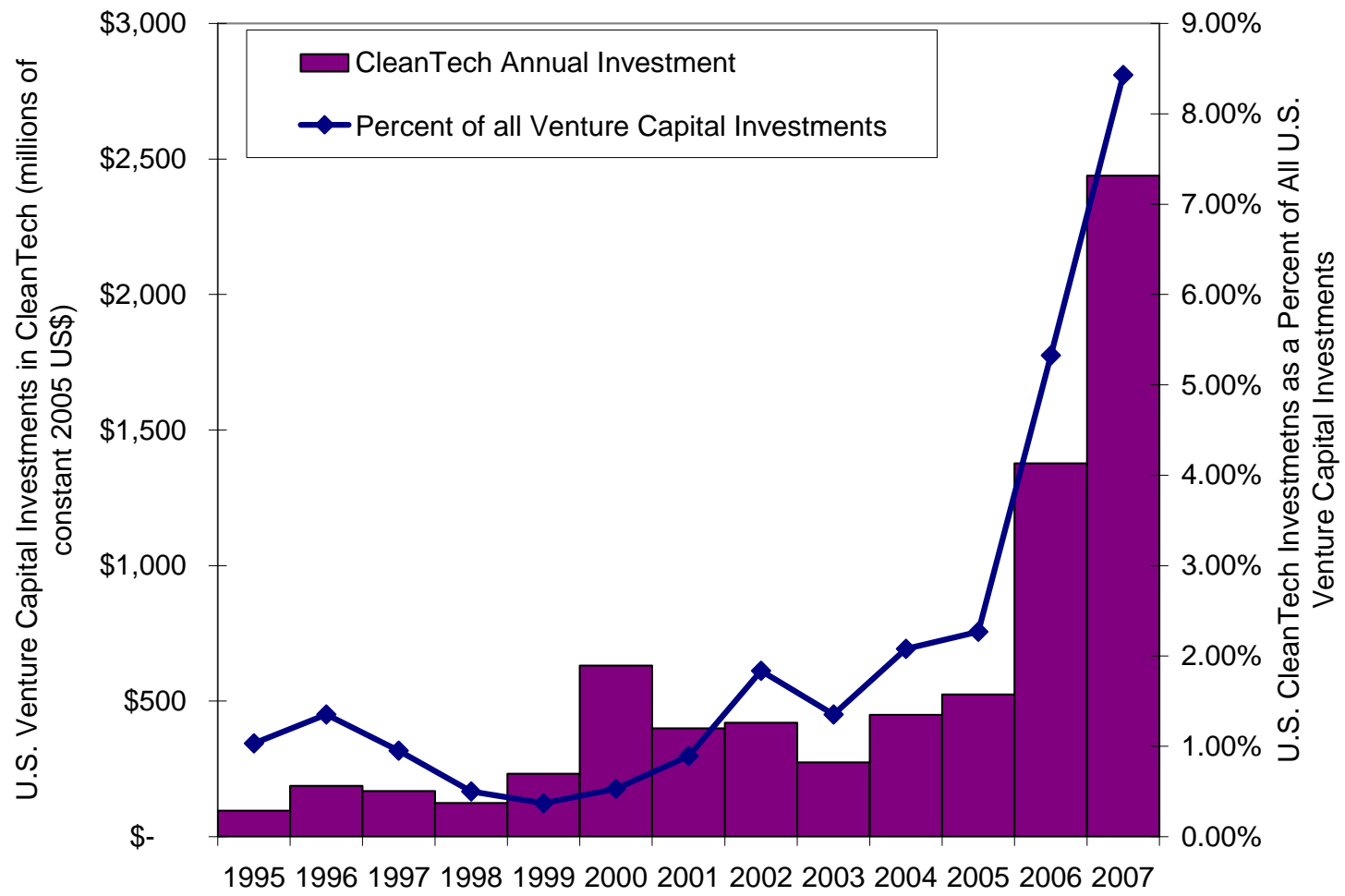

Figure 7. U.S. Venture Capital Investments in CleanTech: 1995-2007 (millions of constant 2005 U.S. dollars)

Significant media attention has been focused on a new cross cutting accounting of U.S. venture capital investments the so called CleanTech sector (i.e., many of the investments listed under "energy / industrial" are also counted under CleanTech). Data for CleanTech investments from 1995-2007 are presented in Figure 7. ${ }^{8}$ The U.S. investments in the CleanTech sector closely follow the pattern seen in the more specific energy / industrial category. In 1995, CleanTech venture capital investments were less than $\$ 100$ million dollars and acconted for $1 \%$ of all U.S. venture capital. By 2007, CleanTech accounted for approximately $\$ 2.4$ billion and slightly more than $8 \%$ of all venture capital investments. ${ }^{9}$

The five largest CleanTech investments in 2007 captured 16\% of all of the investments in this area yet represented only $2 \%$ of the 228 CleanTech deals made that year. The top 5 CleanTech U.S. venture capital investments for 2007 were $^{10}$ :

- \$115 million for GreatPoint Energy, a company planning to build facilities to create syngas from coal, biomass, or other carbonaceous feedstocks;

\footnotetext{
${ }^{8}$ PricewaterhouseCoopers, 2008b, describes CleanTech as follows: "The cleantech sector is not one tidy group, but rather an array of distinct sub-sectors: solar, wind, and geothermal energy generation, biofuels, energy storage (power supplies such as batteries and uninterruptible power supplies), nuclear, new pollution-abatement, recycling, clean coal, and water technologies. The common thread is that all of these sub-sectors represent technologies, services, or products aimed at reducing greenhouse gas emissions and other pollutants and promoting energy efficiency and the conservation of natural resources.”

${ }^{9}$ Quantitative data on CleanTech investments since 1995 are taken from PricewaterhouseCoopers/National Venture Capital Association. 2008.

${ }^{10}$ Quantitative data on the amounts invested in these five deals as well as the descriptions of each company are from PricewaterhouseCoopers, 2008b.
} 
- \$101 million for HelioVolt Corp, a company developing a technology for depositing thinfilm photovoltaic coatings;

- $\quad \$ 76$ million for Advent Solar Inc., a company that produces photovoltaic cells;

- $\$ 70$ million for Imperium Renewables, Inc., a producer of biofuels including biodiesel and bio-derived jet fuel;

- \$64 million for A123Systems, Inc; a producer of lithium-ion batteries for a number of market sectors including plug-in hybrid vehicles.

\section{Conclusions}

The U.S. venture capital and the financial resources it controls have grown significantly since 1980. The focus of U.S. venture capital investments has shifted significantly over this nearly 30 year period as this class of investors have sought out dynamic, fast growing, high potential return investment opportunities. Computer hardware, computer software, medical devices, biotechnology companies and internet-specific companies have all for relatively brief periods of time been the single largest recipient of U.S. venture capital investments. Energy related venture capital investments can only claim to have been the largest recipient of U.S. venture capital funds in the early 1980s, that is in the immediate aftermath of the energy crises of the 1970s and early 1980s. Recent significant increases in the price of oil correlate well with increased venture capital support for energy / industrial firms as well as in the so called "CleanTech" sector. Between 2004 and 2007, U.S. venture capital investments in energy / industrial as well as CleanTech have more than quadrupled in real terms. 


\section{References}

Council of Economic Advisors. 2006. Economic Report of the President: 2006. Appendix B Spreadsheet Tables. http://www.gpoaccess.gov/eop/tables06.html. Executive Office of the President. February 2006. Washington, D.C.

Ehrlich, David. “How green is your drywall?” Cleantech Group. September 5, 2007. http://media.cleantech.com/1704/how-green-is-your-drywall

EverPower Renewables. 2008. About the Company. http://www.everpower.com/about.html

iGPS. 2008 http://www.igps.net/whatWeOffer.php

National Science Board, Science and Engineering Indicators - 2002. Arlington, VA: National Science Foundation, 2002 (NSB-02-1).

National Science Board. National Science Foundation. Science and Engineering Indicators 2008. Arlington, VA. NSB 08-01; NSB 08-01A. January 2008.

National Venture Capital Association. 2007. Frequently Asked Questions.

http://www.nvca.org/faqs.html

PricewaterhouseCoopers. 2008a. MoneyTree ${ }^{\mathrm{TM}}$ Report Definitions and Methodology https://www.pwcmoneytree.com/MTPublic/ns/nav.jsp?page=definitions

PricewaterhouseCoopers. 2008b. “Cleantech comes of age.” April 2008. https://www.pwcmoneytree.com/MTPublic/ns/moneytree/filesource/exhibits/Cleantech\%20come s\%20of\%20age_FINAL.pdf

PricewaterhouseCoopers. 2007. Downloaded data describing Fourth Quarter 2007 Venture Capital Investments in the Energy / Industrial sector.

PricewaterhouseCoopers/National Venture Capital Association. 2008. "MoneyTree ${ }^{\mathrm{TM}}$ Report: Total US Investment by Year Q1 1995 to Q2 2008.” July 19, 2008. https://www.pwcmoneytree.com/MTPublic/ns/nav.jsp?page=historical

Project Better Place. 2008. http://www.betterplace.com/better-place

Reuters.2008. "Renewable Chemicals Corporation Will Use Sugar Cane Ethanol to Manufacture Renewable Chemical.” July 25, 2008. http://www.reuters.com/article/pressRelease/idUS214898+25-Jul-2008+BW20080725 